\title{
PARADIGMA TEOLOGI PENDIDIKAN ISLAM: KONSEP KHALIFAH PERSPEKTIF NILAI-NILAI ETIKA BUDAYA SUNDA DI JAWA BARAT
}

\section{THE PARADIGM OF ISLAMIC EDUCATION THEOLOGY: THE CHALIPH CONCEPT ON PERSPECTIVE OF SUNDANESE CULTURAL ETHICAL VALUES IN WEST JAVA}

\author{
Hisny Fajrussalam \\ Universitas Pendidikan Indonesia \\ hfajrussalam@upi.edu \\ Nurwadjah Ahmad E.Q. \\ Program Pascasarjana UIN Sunan Gunung Djati Bandung \\ nurwadjah.ahmad@gmail.com \\ Andewi Suhartini \\ Program Pascasarjana UIN Sunan Gunung Djati Bandung \\ andewi.suhartini@uinsgd.ac.id
}

\begin{abstract}
Abstrak
Tulisan ini dilatarbelakangi oleh dampak pandemi Covid-19 dan program Pembatasan Sosial Berskala Besar (PSBB) terhadap sosial-ekonomi di Indonesia, khususnya Jawa Barat. Di Jawa Barat sendiri, dukungan masyarakat terhadap program PSBB dinilai paling rendah di Indonesia. Sehingga penelitian ini betujuan untuk menjawab kebutuhan akan sikap yang harus diambil masyarakat Jawa Barat dalam menghadapi pandemi Covid-19 dalam perspektif khalifah sebagai tujuan hidup manusia berbasis nilai-nilai etika budaya Sunda. Penelitian menggunakan pendekatan kualitatif. Data bersumber dari al-Qur'an, kitab tafsir, hadis, buku, artikel jurnal, dan referensi yang relevan. Data yang diperoleh kemudian dikompulasi, dianalisis dan disimpulan dengan menggunakan teknik analysis content. Hasil penelitian menunjukan bahwa sikap yang harus diambil masyarakat Jawa Barat tergategorikan ke dalam empat ajaran dalam agama Islam, yakni aqidah, akhlak, tasawuf, dan mu'amalah.
\end{abstract}

Kata Kunci: khalifah, tujuan hidup, nilai-nilai etika, pandemi Covid-19

\begin{abstract}
This paper is based on the impact of the Covid-19 pandemic and the Large-Scale Social Limitation (PSBB) program on socio-economic development in Indonesia, in particular West Java. In West Java itself, public support for the PSBB program is lowest in Indonesia. So, this study aims to address the needs of the attitude that the people of West Java must face in facing the Covid-19 pandemic in the perspective of the caliph as a purpose of human life based on the ethical values of Sunda culture. Research using qualitative approach. Data is sourced from the Qur'an, interpretive books, hadiths, books, journal articles, and relevant references. The data obtained were then compiled, analyzed and inferred using content analysis techniques. The results show that the attitude that the people of West Java should take is divided into four teachings in Islam, namely beliefs, morals, sufism, and mu'amalah.
\end{abstract}

Keywords: chaliph, purpose of human life, ethical values, pandemic Covid-19 


\section{Pendahuluan}

Saat ini, dunia telah dilanda demam pandemi baru yakni Coronavirus Deases (Covid-19) yang muncul di akhir tahun 2019 di Cina. Indonesia termasuk salah satu negara yang terdampak imbas penyebaran pandemi ini. Data terakhir yang diperoleh dari Gugus Tugas Percepatan Penanganan Covid-19 yang diambil dari 34 Provinsi di Indonesia menunjukan bahwa 17.514 kasus terkonfirmasi (bertambah sebanyak 489 kasus), 12.237 pasien dalam perawatan (69,9\% dari kasus terkonfirmasi), 4.129 pasien sembuh (23,6\% dari kasus terkonfirmasi), dan 1.148 pasien meninggal dunia (6,6\% dari kasus terkonfirmasi) (Gugus Tugas Percepatan Penanganan Covid-19, 2020b). Ironisnya, saat ini masih banyak masyarakat Indonesia yang belum memperoleh informasi detail mengenai bahaya pandemi Covid-19. Mayoritas golongan masyarakat ini adalah kaum anak-anak dan disabilitas (Gugus Tugas Percepatan Penanganan Covid-19, 2020a). Sehingga diperlukan adanya uluran tangan dari masyarakat terhadap mereka yang tidak memperoleh informasi secara utuh mengenai pandemi Covid-19 agar penanganan terhadap pandemi ini dapat segera diselesaikan.

Di sisi lain, Islam mengajarkan umatnya untuk saling menolong dalam kebaikan. Nabi Muhammad saw. telah mengamanatkannya dalam sebuah hadis:

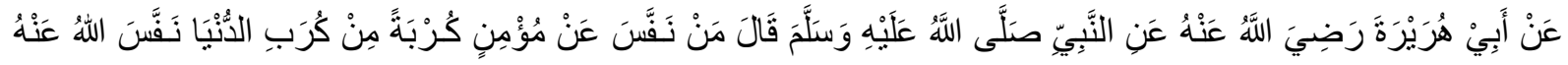

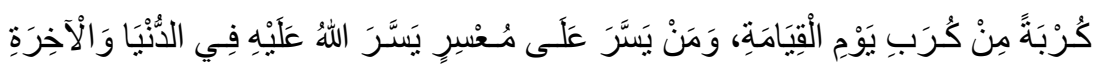

Artinya: "Dari Abu Hurairah Radhiyallahu anhu, Nabi shallallahu 'alaihi wa sallam bersabda, barangsiapa yang melapangkan satu kesusahan dunia dari seorang Mukmin, maka Allah melapangkan darinya satu kesusahan di hari kiamat.” (Qasthalani, t.t., hlm. 138)

Hadis di atas memang cenderung memposisikan umat Islam sebagai mayoritas kaum yang ditolong, karena sejatinya menolong saudara seiman akan mendapatkan pahala di sisi Allah swt. Akan tetapi dalam konsep Islam sebagai agama yang universal dan praktek kehidupan sosial di lingkungan masyarakat yang majemuk, sikap tolong-menolong juga dianjurkan bagi mereka berlainan agama tanpa memandang budaya, ras, dan suku. Allah swt. berfiman:

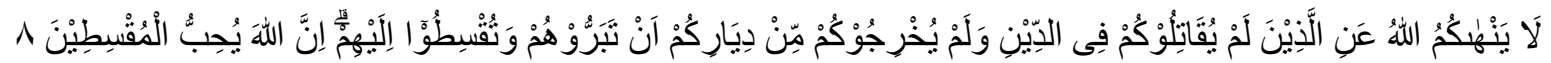

Artinya: "Allah tidak melarang kamu berbuat baik dan berlaku adil terhadap orang-orang yang tidak memerangimu dalam urusan agama dan tidak mengusir 


\section{AL-ADABIYAH: Jurnal Pendidikan Agama Islam}

kamu dari kampung halamanmu. Sesungguhnya Allah mencintai orang-orang yang berlaku adil." (Q.S. al-Mumtahanah: 8)

Sementara itu, manusia sebagai khalifah dan mahkluk paling sempurna yang diciptakan Allah swt. dengan dianugrahkan panca indera dan hati memiliki peran penting dalam memahami alam semesta dan tanda-tanda kebesaran Allah swt. (Nizar \& Al-Rasyidin, 2005, hlm. 18). Konteks memahami alam semesta juga termasuk ke dalamnya memahami realitas sosial di masyarakat. Dalam hal ini, realitas sosial yang terjadi di Indonesia adalah fakta penyebaran pandemi Covid-19 yang menyebabkan sebagian masyarakat tidak menerima informasi yang utuh (Gugus Tugas Percepatan Penanganan Covid-19, 2020a) dan mayoritas masyarakat terkena dampak sosial-ekonomi sebagai akibat dari program PSBB (Pembatasan Sosial Berskala Besar) ("Bantuan Sembako untuk Masyarakat Terdampak COVID19," 2020).

Khususnya Jawa Barat sebagai provinsi dengan jumlah penduduk paling besar di Indonesia, dampak pandemi Covid-19 ini sangat dirasakan. Jawa Barat yang merupakan masyarakat Sunda dengan kondisi masyarakat yang majemuk yang di dalamnya terdapat beragam agama, etnis, dan warna disinyalir berimplikasi langsung pada kondisi dan perilaku sosial masyarakat. Sementara itu, dalam menghadapi pandemi Covid-19, masyarakat Jawa Barat diintruksikan untuk melakukan pembatasan dalam segala kegiatan untuk menekan penyebaran pandemi Covid-19, program yang dimaksud adalah PSBB (Pembatasan sosial berskala besar) (Gubernur Jawa Barat, 2020). Akan tetapi, menurut lembaga survei Saiful Mujani Research \& Consulting (SMRC), Provinsi Jawa Barat memiliki tingkat dukungan paling rendah terhadap aturan-aturan dalam Pembatasan Sosial Berskala Besar (PSBB). Peneliti SMRC Sirajuddin Abbas menuturkan, berdasarkan survei yang dilakukan pihaknya secara umum, warga di Jawa Barat terlihat memiliki kesadaran yang paling rendah akan bahaya penyakit ini dibanding wilayah lain (Irfan, 2020). Di sisi lain, mulai bulan Juni pemerintah Jawa Barat hendak memberlakukan tatanan normal baru atau new normal (Humas Jabar, 2020). Pertanyaanya adalah apa yang harus dilakukan masyarakat Jawa Barat sebagai khalifah di muka bumi dalam rangka menghadapi pandemi Covid-19 dan new normal?

Oleh karenanya, tulisan kecil ini akan mencoba menjawab pertanyaan tersebut. Walaupun penulis menyadari dengan keterbatasan yang dimiliki tidak akan secara utuh memaparkan hal tersebut, setidaknya penulis telah mencoba untuk mewacanakannya dalam tulisan singkat ini. 


\section{Tinjauan Literatur}

\section{Teologi Pendidikan Islam: Definisi dan Sejarah Singkatnya}

Dalam literatur Barat, istilah teologi banyak digunakan untuk agama Kristen, yaitu suatu kepercayaan atau dogma yang menjadi dasar keyakinan. Sementara dalam agama Islam, istilah teologi lebih banyak digunakan degan sebutan ilmu kalam atau ilmu tauhid (Syafi'e, 2013, hlm. 2). Walaupun demikian, teologi pada hakikatnya adalah sama-sama membicarakan mengenai keesaan Tuhan. Dalam kontek Islam, teologi adakalanya lebih baik disandingkan dengan term "Islam" untuk menegaskan bahwa teologi yang dimaksud adalah teologi yang bernafaskan agama Islam.

Teologi itu sendiri berasal dari bahasa Inggris theologi dan dari bahasa Yunani theologia (berakar dari dua kata, yakni theos yang berarti Tuhan dan logos yang berarti wacana ilmu) (Syafi'e, 2013, hlm. 2). Secara sederhana, Hidayat mendefinisikan teologi sebagai penalaran kritis tentang Tuhan (Hidayat, 2004, hlm. 189). Menurutnya, teologi muncul dari tradisi dan semangat beragama sehinga di dalamnya terkandung semangat iman dan pembenaran wahyu Tuhan. Teologi selalu dibedakan dari filsafat ketuhanan yang memberikan kebebasan pada nalar dalam membahas persoalan Tuhan tanpa terikat dengan wahyu (Hidayat, 2004, hlm. 189; Suryadi, 2014, hlm. 118). Sehingga teologi pendidikan Islam pada hakikatnya adalah konsep pendidikan Islam yang berlandaskan al-Qur'an dan Hadis untuk mencapai derajat kehambaan yang tinggi di sisi Tuhan, Allah 'Azza wa Jalla.

Menurut sejarahnya, teologi pendidikan Islam muncul karena ada "intervensi" filsafat keilmuan Barat yang menyebabkan kaum intelektual muslim memiliki standar rendah dan selalu bergantung kepada Barat (Al-Faruqi, 2000, hlm. 105; Siswanto, 2006, hlm. 18). Sehingga konsep teologi pendidikan Islam mucul untuk menawarkan kesatuan ilmu pengetahuan dengan konsep Islam. Selain itu, gagasan ini juga muncul karena adanya dikotomi antara agama yang cenderung eksklusifliteralis-apologetis dan ilmu pengetahuan yang dibawa masyarakat Barat serta budaya masyarakat modern (Nata, 2003, hlm. 97).

\section{Konsep Khalifah Berdasarkan Teologi Pendidikan Islam}

Term khalifah berasal dari kata خلف yang berarti belakang. Kata ini sering juga diartikan sebagai pengganti. Pengganti di sini bermakna pengganti dari generasi ke 


\section{AL-ADABIYAH: Jurnal Pendidikan Agama Islam}

generasi untuk meneruskan ajaran dan hukum yang berasal dari Allah swt. (Lisnawati, Abdussalam, \& Wibisana, 2015, hlm. 51). Senada dengan (Muhaimin, Sutiah, \& Ali, 2008, hlm. 22) yang mengatakan bahwa khalifah berasal dari kata khalf atau dari kata khalaf sebagai lawan dari kata salaf. Kata khalifah dapat ditemukan dalam Q.S. al-Baqarah ayat 30 yang berbunyi:

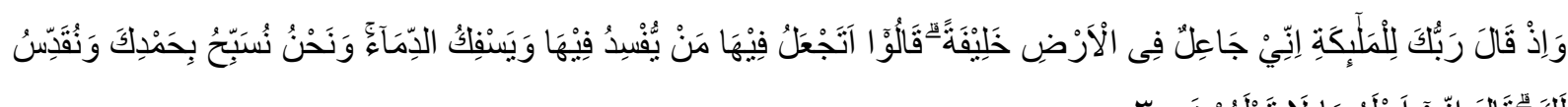

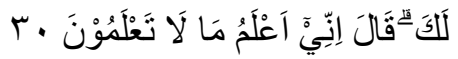

Artinya: "Dan (ingatlah) ketika Tuhanmu berfirman kepada para malaikat, "Aku hendak menjadikan khalifah di bumi." Mereka berkata, "Apakah Engkau hendak menjadikan orang yang merusak dan menumpahkan darah di sana, sedangkan kami bertasbih memuji-Mu dan menyucikan nama-Mu?" Dia berfirman, "Sungguh, Aku mengetahui apa yang tidak kamu ketahui."

Kata khalifah pada ayat di atas mulanya berarti yang menggantikan atau yang datang sesudah siapa yang datang sebelumnya. Atas dasar ini, ada yang memahami kata khalifah di sini dalam arti menggantikan Allah dalam menegakan kehendakNya dan menerapkan ketetapan-ketetapan-Nya, tetapi bukan karena Allah tidak mampu atau menjadikan manusia berkedudukan sebagai Tuhan, namun karena Allah bermaksud menguji manusia dan memberinya penghormatan. Ada lagi yang memahaminya dalam arti yang menggantikan mahluk lain dalam menghuni bumi ini (Syihab, 2007, hlm. 82).

Agar dapat menjadi khalifah yang seutuhnya, semua tugas dan peran khalifah di muka bumi sangatlah memerlukan pengetahuan. Ketika seorang khalifah ditugaskan untuk menegakan hukum-hukum Allah, maka Allah memerintahkan kepadanya untuk tidak mengikuti hawa nafsunya. Seperti dalam surat Șad ayat 26 yang tentu saja menuntut sang khalifah untuk mengetahui hukum-hukum tersebut dan mempunyai kekuatan untuk melakukannya. Karena seperti tertera dalam hadis Nabi, yang artinya,

"Dari Abu Sa'id al-Khudri r.a. ia berkata, "Aku mendengar Rasulullah saw. bersabda: "Barangsiapa diantara kalian melihat kemunkaran, maka hendaklah ia merubahnya dengan tangannya, jika tidak mampu, maka dengan lisannya, dan jika tidak mampu maka dengan hatinya. Yang demikian itu selemah-lemahnya iman" (H.R. Muslim) (Lisnawati dkk., 2015, hlm. 52).

\section{Metode}




\section{AL-ADABIYAH: Jurnal Pendidikan Agama Islam}

Penelitian ini menggunakan pendekatan kualitatif. Data bersumber dari alQur'an, kitab tafsir, hadis, buku, artikel jurnal, dan referensi yang relevan. Data yang diperoleh kemudian dikompulasi, dianalisis dan disimpulan dengan menggunakan teknik analysis content.

\section{Hasil dan Diskusi}

\section{Khalifah sebagai Sebuah Tujuan Hidup Manusia}

Orang Islam memahami bahwa hidup di dunia ini mempunyai tugas yang jelas, yaitu beribadah kepada Allah swt. Tugas ibadah ini sebagaimana tercantum dalam Q.S. al-Dzariat ayat 56 sebagai berikut:

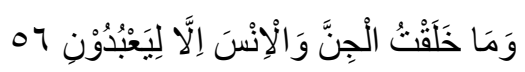

Artinya: "Aku tidak menciptakan jin dan manusia melainkan agar mereka beribadah kepada-Ku."

Pelaksanaan tugas ibadah ini amat terkait dengan fungsi hidup manusia di dunia ini, yaitu sebagai "hamba Allah" (abdullah) dan "khalifah Allah" (khalifatullah). Sebagai hamba Allah, orangIslam menyadari bahwa dirinya mempunyai kewajiban untuk mengabdi, bertaqarrub, atau beribadah langsung kepada-Nya (hablum minallah), melalui ibadah mahdhah (ibadah ritual-personal, seperti: shalat, shaum, dan berdoa), dan ibadah ghoir mahdhah (ibadah sosial, yaitu ibadah kepada Allahmelalui hablum minannas, yang dalam pelaksanaannya melalui fungsi sebagai khalifah Allah).

Sebagai khalifah Allah, orang Islam menyadari bahwa dirinya mengemban amanah atau tanggung jawab (responsibility) untuk mewujudkan misi suci kemanusiaannya sebagai "rahmatan lil "alamiin" (rahmat bagi seluruh alam). Upaya yang ditempuh untuk mewujudkan misi tersebut adalah dengan senantiasa berinisiatif dan berpartisipasi aktif dalam menciptakan tatanan kehidupan masyarakat yang nyaman, sejahtera, dan jalinan persaudaraan serta kasih sayang antar sesama, dan berupaya mencegah terjadinya pelecehan nilai-nilai kemanusiaan, penindasan terhadap kaum mustadl'afin (kaum lemah, miskin, atau orang-orang yang dimarjinalkan)dan pengrusakan lingkungan hidup (baik lokal, regional, maupun global).

Manusia diciptakan Allah dari intisari tanah yang dijadikan nuthfah dan disimpan di tempat yang kokoh. Kemudian nuthfah itu dijadikan darah beku, darah beku itu dijadikan mudghah, mudghah dijadikan tulang, tulang dibalut dengan daging yang kemudian dijadikan Allah makhluk lain al-Quran ([23]: 12-16). Sehingga 
manusia lahir ke muka bumi dengan difasilitasi akal dan panca indera sebagai sebuah kesempurnaan ciptaan Yang Maha Kuasa, Allah swt. Kesempurnaan pencitptaan yang demikian membuat manusia menempati kedudukan tertinggi diantara makhluk, yakni menjadi khalifah (wakil) Tuhan di muka bumi, seperti diisyaratkan oleh surat al-Baqarah ayat 30 .

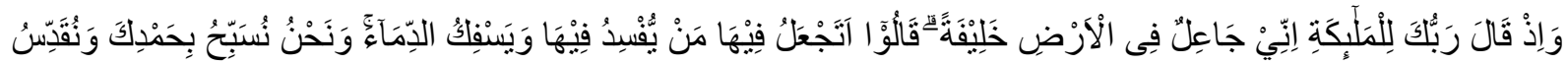

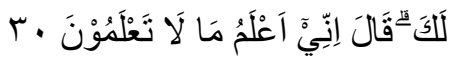

Artinya: "Dan (ingatlah) ketika Tuhanmu berfirman kepada para malaikat, "Aku hendak menjadikan khalifah di bumi." Mereka berkata, "Apakah Engkau hendak menjadikan orang yang merusak dan menumpahkan darah di sana, sedangkan kami bertasbih memuji-Mu dan menyucikan nama-Mu?" Dia berfirman, "Sungguh, Aku mengetahui apa yang tidak kamu ketahui."

Kendati manusia memiliki potensi kesempurnaan sebagai gambaran dari kesempurnaan citra ilahi, tetapi kemudian ketika ia terjatuh dari prototip ketuhanan, maka kesempurnaan itu semakin berkurang. Untuk itu, jalan satusatunya mencapai kesempurnaan itu ialah kembali kepada Tuhan dengan iman dan amal saleh. Dengan demikian makna khalifah secara lebih dalam adalah berpuncak pada insan kamil. Insan kamil membawa misi moral dan intelektual. Dengan dilengkapi akal dan kemampuan mengkonseptualisasikan, manusia diberi petunjuk melalui wahyu Tuhan dalam terma-terma keutamaan moral. Kehidupannya di alam raya ini baginya adalah wahana ujian baginya. Oleh karena itu, manusia memegang tanggung jawab kekhalifahan yang harus dipertanggungjawabkan di hadapan Allah SWT.

Kedudukan manusia dalam sistem penciptaanya adalah sebagai hamba Allah sekaligus sebagai khalifah di bumi ini. Kedudukan itu berhubungan dengan peranan yang ideal. Yaitu pola perilaku yang di dalamnya terkandung hak, kewajiban, dan tugas manusia yang terkait dengan kedudukannya di hadapan Allah sebagai pencipta. Dengan demikian, manusia diciptakan bukan sekedar untuk hidup mendiami dunia ini dan kemudian mengalami kematian tanpa adanya pertanggung jawaban kepada pencipta-Nya, melainkan manusia diciptakan oleh Allah untuk mengabdi kepada-Nya.

\section{Nilai-nilai Etika Budaya Sunda}

Kebudayaan suatu bangsa adalah jati diri yang harus dipelajari dan dipertahankan dengan baik. Karena itu untuk mempertahankannya diperlukan 


\section{AL-ADABIYAH: Jurnal Pendidikan Agama Islam}

kecerdasan dalam memaknai suatu makna kebudayaan. Kebudayaan memiliki makna inovasi dan perubahan, dan kebudayaan adalah sumber dari perubahan itu sendiri (Sulhan, 2018, hlm. 163). Pendidikan karakter berbasis budaya merupakan pendidikan yang mengajarkan untuk senantiasa dekat dan siap dengan situasi konkret yang dihadapi (Istiawati, 2016, hlm. 7). Pendidikan karakter berbasis budaya memaknai budaya sebagai suatu hal yang harus dipelajari, dipelihara dan ditransformasikan ke generasi selanjutnya.

Hubungan fungsional antara pendidikan dan kebudayaan mengandung dua makna, yaitu pertama bersifat reflektif, yakni gambaran kebudayaan yang berlangsung saat ini, dan kedua besifat progresif, yaitu pendidikan yang bergerak melakukan pembaharuan, membawa kebudayaan ke arah peradaban yang maju. Reflektif dan progresif ini merupakan dua hal dimana proses pendidikan itu merupakan usaha individu sekaligus upaya inovatif dan dinamis dalam rangka menghadapi perubahan zaman ke arah yang lebih baik lagi (Sulhan, 2018, hlm. 163). Sehingga dapat dikatakan bahwa pendidikan karakter merupakan akhir dari suatu proses pendidikan.

Sementara itu budaya diartikan sebagai gagasan mengenai kehidupan. Pemikiran seperti itu didasarkan pada perenungan yang jernih, pikiran yang murni, dan berisi hal-hal positif. Budaya juga dapat diterjemahkan sebagai karya pikiran, perasaan yang mendalam, dan karakter (Sulasmono, Ekosiswoyo, \& Widodo, 2017, hlm. 153). Kearifan budaya erat hubungannya dengan istilah suku bangsa. Suku bangsa adalah golongan manusia yang terikat oleh kesadaran dan identitas akan "kesatuan kebudayaan", dan unsur bahasa adalah ciri khasnya (Nuraeni \& Alfan, 2012, hlm. 64).

Sehingga kearifan budaya Sunda dapat didefinisikan sebagai suatu kondisi sosial dan budaya yang didalamnya terkandung khazanah nilai-nilai karakter berbasis budaya yang menghargai dan adaptif dengan alam sekitar serta tertata secara ajeg dalam suatu tatanan adat istiadat di dalam suatu masyarakat. Walau sering dianggap kuno, nilai-nilai yang mereka ajarkan dan praktekan masih merupakan cara yang terbaik untuk memelihara lingkungan di zaman post-modern (Indrawardana, 2013, hlm. 1). Masyarakat Sunda sebagai komunitas yang memegang teguh budaya Sunda bukanlah sekumpulan manusia yang menghubungkan individu satu dengan lainnya dan individu satu dengan masyarakat, melainkan merupakan satu kesatuan yang lekat erat satu sama lain oleh norma-norma hidup karena sejarah, tradisi maupun religi. Keluarga, sebagai 
unit terkecil memiliki peran sebagai simpul perekat satu dengan yang lainnya untuk ditarik ke wilayah yang lebih luas lagi yaitu kampung, desa, Negara hingga dunia.

Nilai-nilai inti karakter Sunda yaitu kesejahteraan, kesehatan, peduli lingkungan, moderat, kerja keras, disiplin, kesopansatunan, kejujuran, menjujung tinggi kebenaran, gotong royong, kesetiakawanan sosial, berpikir postif, matang perhitungan, pendidikan, pengelolaa gender, dan pelestarian serta kreativitas budaya.

Nilai-nilai tersebut tercermin dalam pandangan hidup, tradisi lisan, babasan/paribasa, dan perilaku pro-sosial yang tumbuh dan berkembang dalam masyarakat Sunda. Secara lebih jelas Fajrussalam \& Hasanah (2018, hlm. 20) telah menggambarkan alur nilai-nilai tersebut pada gambar berikut.

Gambar 1. Alur Nilai-nilai Karakter Sunda

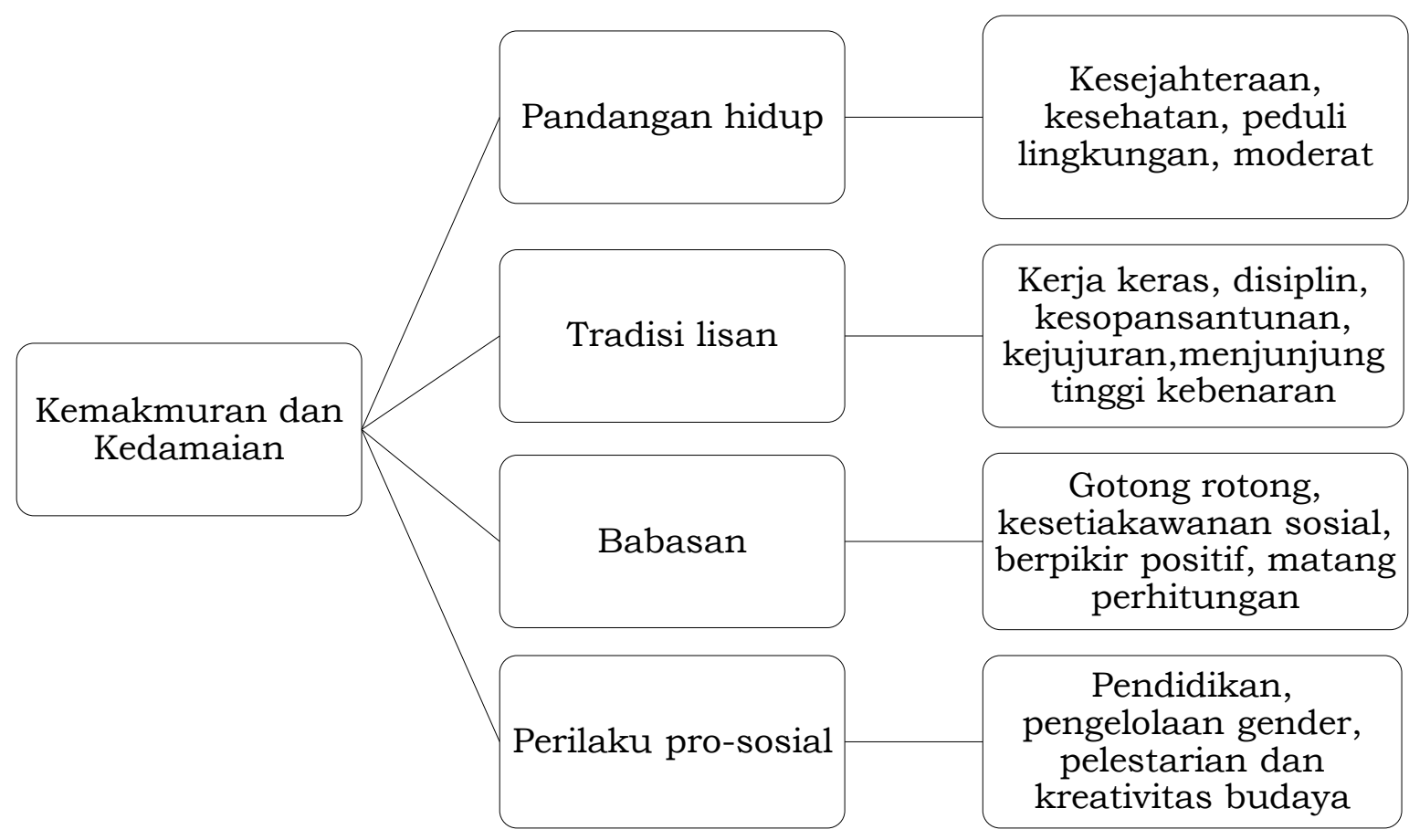

Sikap yang Harus Diambil Masyarakat Jawa Barat dalam Menghadapi Pandemi Covid-19 dan New Normal

Berdasarkan paparan sebelumnya mengenai nilai-nilai budaya Sunda, maka konsep khalifah sebagai sebuah tujuan hidup manusia sebenarnya merupakan tujuan hidup bersama, khususnya masyarakat Jawa Barat sebagai sebuah komunitas Sunda. Sehingga, penanaman terhadap nilai-nilai etika tersebut adalah interpretasi masyarakat Sunda sebagai khalifah di Jawa Barat. Nilai-nilai yang 
dimaksud adalah kesejahteraan, kesehatan, peduli lingkungan, moderat, kerja keras, disiplin, kesopansatunan, kejujuran, menjunjung tinggi kebenaran, gotong royong, kesetiakawanan sosial, berpikir positif, matang perhitungan, pendidikan, pengelolaan gender, pelestarian dan kreativitas budaya. Jika dikategorikan berdasarkan ajaran agama Islam, maka nilai-nilai etika budaya Sunda dapat dilihat pada gambar berikut:

Gambar 2. Integrasi Nilai-nilai Etika Budaya Sunda dengan Ajaran Agama Islam

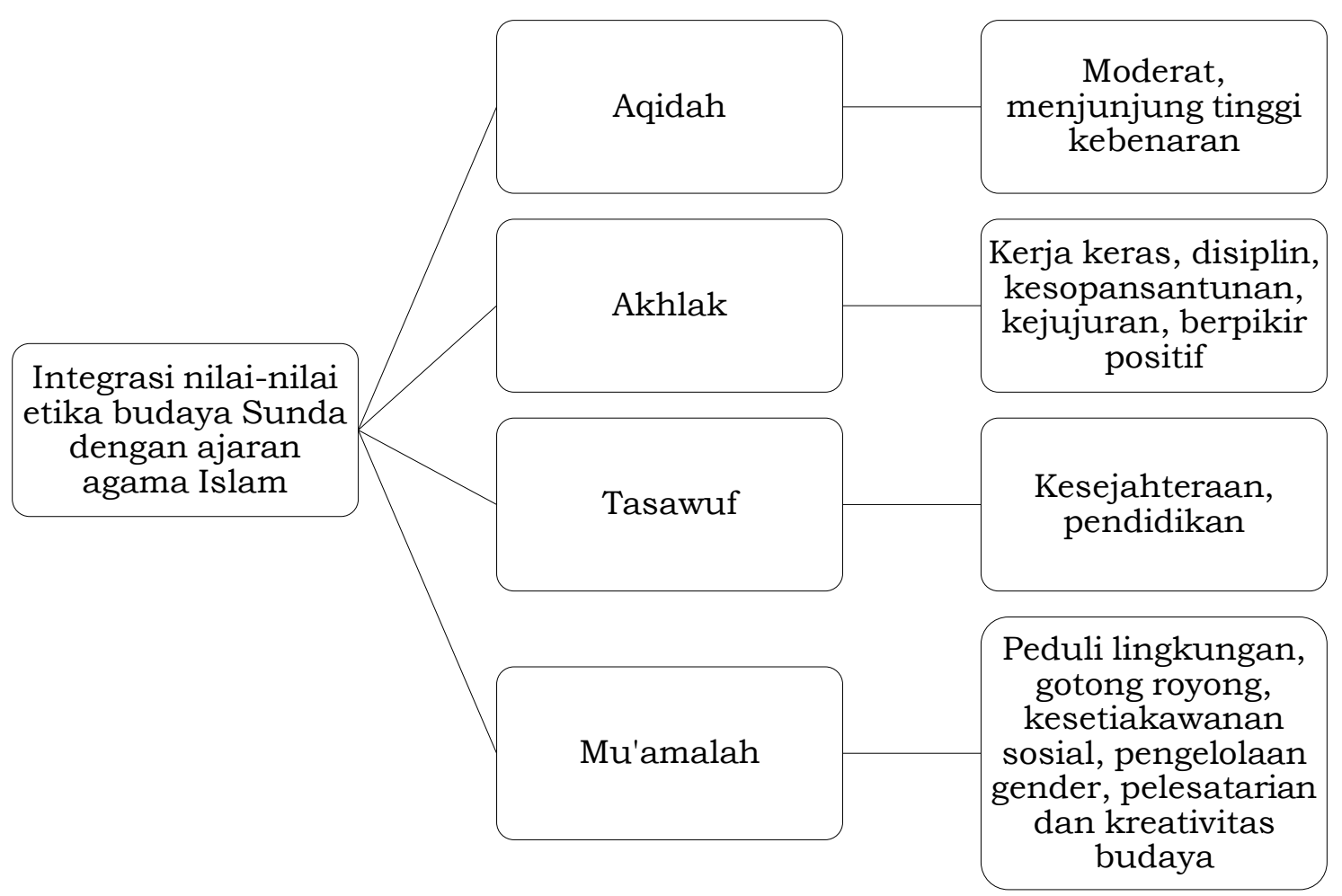

Pertama, aqidah sebagai pondasi kehidupan beragama harus senantiasa dipelihara. Sikap moderat dan menjunjung tinggi kebenaran harus diambil masyarakat Jawa Barat dalam rangka menghadapi pandemi Covid-19 dan new normal. Sikap yang dimaksud adalah dengan meyakini bahwa pandemi Covid-19 merupakan sebuah takdir dari Allah swt. dan manusia diharuskan untuk berusaha menghindarinya semaksimal mungkin. Sikap ini ditempuh sebagai upaya untuk menumbuhkan sikap tawasuth, tawazun dan tasamuh (Wahyudin, 2017, hlm. 291). Hal ini bukanlah tanpa sebab, karena sebagian masyarakat ada yang meyakini bahwa pandemi Covid-19 merupakan takdir dari Allah swt. dan kalaupun manusia ditakdirkan untuk terkenal virus tersebut kemudian meninggal, hal itu senantiasa karena takdir dari Allah semata, sehingga manusia tidak memiliki kemampuan 


\section{AL-ADABIYAH: Jurnal Pendidikan Agama Islam}

apapun untuk menghidari virus tersebut. Sehingga pemikiran masyarakat seperti ini condong kepada aliran Jabariyah (Suhaimi, 2019, hlm. 108). Di sisi lain, ada juga sebagian yang menyatakan bahwa pandemi Covid-19 ini merupakan ulah manusia sendiri tanpa ada campur tangan Allah swt., sehingga manusialah yang harus bertanggungjawab penuh terhadap penyebaran pandemi Covid-19 di seluruh dunia dan bersungguh-sungguh untuk menghentikan polemik ini. Hal ini agaknya senada dengan pendapat Qodariyah dalam aliran ilmu kalam (Samad, 2013, hlm. 72).

Kedua, sikap yang harus diambil masyarakat Jawa Barat adalah mengenai akhlak. Imam al-Ghazali mendefinisikan akhlak sebagai suatu sifat yang tertanam dalam jiwa yang dari padanya timbul perbuatan-perbuatan dengan mudah, dengan tidak memerlukan pertimbangan pikiran (lebih dahulu) (Al-Ghazali, t.t., hlm. 56; Kementerian Agama RI, 2012, hlm. 301). Akhlak dalam hal ini adalah kerja keras dan disiplin. Kerja keras dan disiplin merupakan faktor yang tidak kalah penting dalam menghadapi pandemi Covid-19 dan new normal. Dengan kerja keras dan disiplin untuk senantiasa mengikuti instruksi pemerintah dan protokol kesehatan, seharusnya pandemi Covid-19 dapat diatasi di Jawa Barat. Dalam ajaran Islam banyak ayat al-Qur'an dan hadis yang memerintahkan disiplin dalam arti ketaatan pada peraturan yang telah ditetapkan (Abdullah, 2015, hlm. 162), antara lain surat an-Nisa' ayat 59:

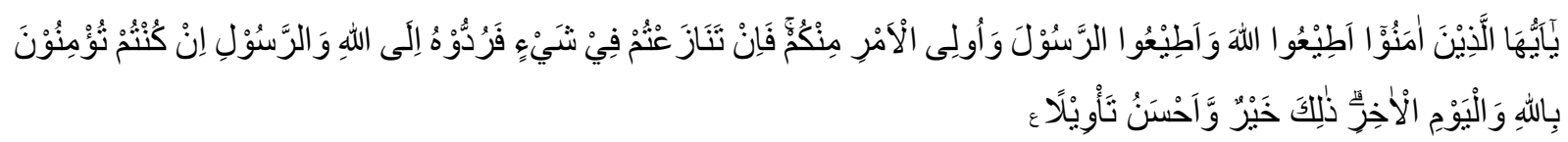

Artinya: "Wahai orang-orang yang beriman! Taatilah Allah dan taatilah Rasul (Muhammad), dan Ulil Amri (pemegang kekuasaan) di antara kamu. Kemudian, jika kamu berbeda pendapat tentang sesuatu, maka kembalikanlah kepada Allah (AlQur'an) dan Rasul (sunnahnya), jika kamu beriman kepada Allah dan hari kemudian. Yang demikian itu lebih utama (bagimu) dan lebih baik akibatnya."

Ketiga, ajaran Islam yang relevan untuk dilakukan masyarakat Jawa Barat saat ini adalah tasawuf. Sebagai khalifah, masyarakat Jawa Barat harus senantiasa mencari informasi mengenai bahaya pandemi Covid-19 dan penerapan new normal sebagai bagian yang tidak terpisahkan dari proses pendidikan. Masyarakat juga diharuskan mencari dan memperoleh kesejahteraan hidup di dunia sampai akhirat (Ramayulis, 2011, hlm. 136). Kesejahteraan yang dimaksud adalah berusaha semaksimal mungkin untuk senantiasa memelihara diri dari virus Covid-19 dengan 


\section{AL-ADABIYAH: Jurnal Pendidikan Agama Islam}

mengikuti intruksi pemerintah dan protokol kesehatan. Allah swt. telah memberikan isyarat yang sangat jelas dalam al-Qur'an:

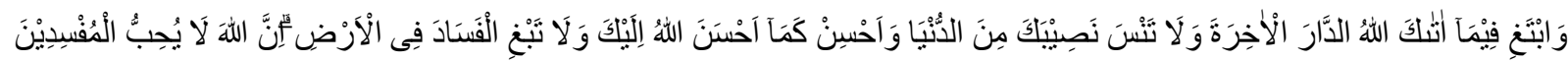

Artinya: "Dan carilah (pahala) negeri akhirat dengan apa yang telah dianugerahkan Allah kepadamu, tetapi janganlah kamu lupakan bagianmu di dunia dan berbuatbaiklah (kepada orang lain) sebagaimana Allah telah berbuat baik kepadamu, dan janganlah kamu berbuat kerusakan di bumi. Sungguh, Allah tidak menyukai orang yang berbuat kerusakan.” (Q.S. al-Qasas: 77)

Kesejahteraan dalam hal ini juga termasuk di dalamnya mencari nafkah untuk kehidupan sehari-hari. Rasulullah saw. pun bersabda:

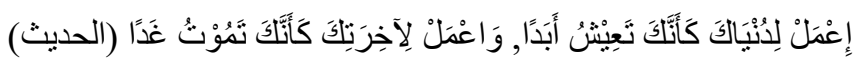

Artinya: "Bekerjalah untuk duniamu seakan-akan kamu akan hidup selamanya, dan bekerjalah untuk akhiratmu seolah-olah kamu akan mati esok hari." (al-Hadis)

Keempat, sikap yang harus ditempuh adalah mengenai mua'amalah. Sikap peduli lingkungan, gotong royong, dan kesetiakawanan sosial harus ditumbuhkan dalam diri masyarakat Jawa Barat. Sikap peduli lingkungan dapat diwujudkan dengan senatiasa menjaga kebersihan dan kelestarian alam walaupun di tengah pandemi Covid-19. Sementara itu sikap gotong royong dan kesetiakawanan sosial diwujudkan dalam bentuk kepedulian terhadap masyarakat yang terdampak pandemi Covid-19 dengan memberikan bantuan. Karena bagaimanapun, kondisi ekonomi saat ini masyarakat Indonesia, khususnya Jawa Barat tengah terpuruk (Kompas, 2020). Dengan demikian bahwa setiap warga apapun latar belakang sosial, politik, suku (nilai-nilai pengelolaan dan kreativitas budaya), ras, golongan, jenis kelamin (nilai-nilai pengelolaan gender) maupun agama harus mendapat jaminan perlindungan menyangkut keselamatan jiwanya. Hal ini bukan saja menyangkut hak asasi manusia, tetapi juga menunjukan betapa Islam sangat menghormati hak hidup bagi setiap mahkluk-Nya. Demikian pentingnya, sehingga al-Qur'an menganggap bahwa membunuh orang lain tanpa hak dianggap membunuh seluruh umat manusia (Kementerian Agama RI, 2012, hlm. 96):

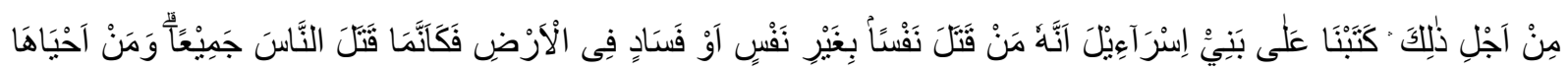

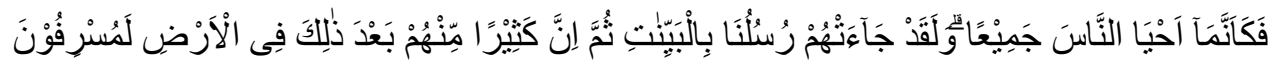




\section{AL-ADABIYAH: Jurnal Pendidikan Agama Islam}

Artinya: "Oleh karena itu Kami tetapkan (suatu hukum) bagi Bani Israil, bahwa barangsiapa membunuh seseorang, bukan karena orang itu membunuh orang lain, atau bukan karena berbuat kerusakan di bumi, maka seakan-akan dia telah membunuh semua manusia. Barangsiapa memelihara kehidupan seorang manusia, maka seakan-akan dia telah memelihara kehidupan semua manusia. Sesungguhnya Rasul Kami telah datang kepada mereka dengan (membawa) keterangan-keterangan yang jelas. Tetapi kemudian banyak di antara mereka setelah itu melampaui batas di bumi." (Q.S. al-Ma’idah: 32)

Ayat di atas ingin menegaskan bahwa hak hidup setiap manusia harus dijaga dan nyawa mereka harus dihormati agar tidak melayang sia-sia (Al-Razi, t.t., hlm. 40). Sehingga bentuk bantuan apapun yang sifatnya menyelematkan jiwa harus dilakukan masyarakat Jawa Barat di tengah pandemi Covid-19 dan new normal tanpa harus mengandalkan pemerintah.

\section{Kesimpulan}

Khalifah sebagai tujuan hidup masyarakat Jawa Barat tidak dapat dipisahkan dari nilai-nilai etika budaya Sunda sebagai identitas Jawa Barat. Nilai-nilai etika tersebut relevan dengan ajaran agama Islam dalam bentuk ajaran aqidah, akhlak, tasawuf, dan mu'amalah. Dalam menghadapi pandemi Covid-19 dan new normal yang tidak lama lagi akan diberlakukan, masyarakat Jawa Barat harus senantiasa menanamkan nilai-nilai etika tersebut dalam kehidupan sehari-hari sehingga masyarakat Jabat dapat menjadi khalifah yang sesungguhnya di tanah Sunda.

\section{Referensi}

Abdullah, W. (2015). Disiplin Kerja dalam Islam. Minds: Jurnal Manajemen Ide dan Inspirasi, 2(1), 152-167. doi: https://doi.org/10.24252/minds.v2i1.4639

Al-Faruqi, I. R. (2000). Hijrah di Abad Modern, terj. Badri Saleh. Jakarta: Hikmah.

Al-Ghazali, A. H. (t.t.). Ihya Ulumuddin. Mesir: Maktabah al-Ulum al-'Arsiyah.

Al-Razi, F. (t.t.). Mafatihul-Ghaib (Vol. 6). Beirut: Dar al-Kutub al-Ilmiyah.

Bantuan Sembako untuk Masyarakat Terdampak COVID-19. (2020, Mei). Diambil 18 Mei 2020, dari News.detik.com website: https://news.detik.com/fotonews/d-5015394/bantuan-sembako-untuk-masyarakat-terdampak-covid-19 
Fajrussalam, H., \& Hasanah, A. (2018). Core Ethical Values of Character Education Based on Sundanese Culture Value. IJECA (International Journal of Education and Curriculum Application), 1(3), 15-22. doi: 10.31764/ijeca.v1i3.2126

Gubernur Jawa Barat. (2020, Mei). Peraturan Gubernur Jawa Barat Nomor 443/Kep.259- Hukham/2020 tentang Pemberlakukan PSBB di Wilayah Provinsi Jawa Barat dalam Rangka Percepatan Penanggulangan COVID-19. Diambil dari https: / www.jabarprov.go.id/index.php/news/37653/2020/05/04/RidwanKamil-Tandatangani-Pergub-PSBB-Wilayah-Jawa-Barat

Gugus Tugas Percepatan Penanganan Covid-19. (2020a, Mei). Pentingnya Membantu Masyarakat Disabilitas di Tengah Pandemi COVID-19. Diambil dari https: / / covid19.go.id/p/berita/pentingnya-membantu-masyarakatdisabilitas-di-tengah-pandemi-covid-19

Gugus Tugas Percepatan Penanganan Covid-19. (2020b, Mei). Peta Sebaran Covid19 di Indonesia. Diambil 18 Mei 2020, dari https://covid19.go.id/petasebaran

Hidayat, K. (2004). Menafsirkan Kehendak Tuhan. Bandung: Teraju.

Humas Jabar. (2020, Mei). Jabar Bersiap Adaptasi dengan Tatanan Normal Baru. Diambil 30 Mei 2020, dari Pusat Informasi dan Koordinasi Covid-19 Provinsi Jawa Barat website: https://pikobar.jabarprov.go.id/articles/jabar-bersiapadaptasi-dengan-tatanan-normal-baru-artcl.kaqpxpjoawym9y4qc0s /

Indrawardana, I. (2013). Kearifan Lokal Adat Masyarakat Sunda dalam Hubungan dengan Lingkungan Alam. Komunitas: International Journal of Indonesian Society and Culture, 4(1), 1-8. doi: 10.15294/komunitas.v4i1.2390

Irfan, M. (2020, April 17). Paling Rendah, Tingkat Dukungan Masyarakat Jawa Barat pada PSBB. pikiranrakyat.com. Diambil dari https://www.pikiranrakyat.com/nasional/pr-01367606/paling-rendah-tingkat-dukunganmasyarakat-jawa-barat-pada-psbb

Istiawati, N. F. (2016). Pendidikan Karakter Berbasis Nilai-Nilai Kearifan Lokal Adat Ammatoa dalam Menumbuhkan Karakter Konservasi. CENDEKIA: Journal of Education and Teaching, 10(1), 1-18. doi: 10.30957/cendekia.v10i1.78

Kementerian Agama RI. (2012). Etika Berkeluarga, Bermasyarakat, dan Berpoliti (Tafsir Al-Qur'an Tematik) (Edisi yang Disempurnakan). Jakarta: Direktorat Jenderal Urusan Agama Islam dan Pembinaan Syariah Direktorat Jenderal Bimas Islam Kementerian Agama RI.

Kompas. (2020). Perekonomian Indonesia Pasca-Pandemi Covid-19. Diambil 31 Mei 2020, dari Kompas.com: Jernih Melihat Dunia website: https: / / money.kompas.com/read/2020/05/10/091500226/perekonomianindonesia-pasca-pandemi-covid-19?page $=$ all

Lisnawati, Y., Abdussalam, A., \& Wibisana, W. (2015). Konsep Khalīfah dalam AlQur`an dan Implikasinya terhadap Tujuan Pendidikan Islam (Studi Maudu'i 
terhadap Konsep Khalīfah dalam Tafsir Al-Misbah). TARBAWY: Indonesian Journal of Islamic Education, 2(1), 47. doi: 10.17509/t.v2i1.3377

Muhaimin, Sutiah, \& Ali, N. (2008). Paradigma Pendidikan Islam di Sekolah. Bandung: Remaja Rosdakarya.

Nata, A. (2003). Manajemen Pendidikan, Mengatasi Kelemahan Pendidikan Islam di Indonesia. Jakarta: Kencana.

Nizar, S., \& Al-Rasyidin. (2005). Filsafat Pendidikan Islam: Pendekatan Historis, Teoritis dan Praktis (Edisi Revisi). Jakarta: Ciputat Pers.

Nuraeni, H. G., \& Alfan, M. (2012). Studi Budaya di Indonesia (Cetakan I). Bandung: CV Pustaka Setia.

Qasthalani. (t.t.). Irsyadus-Sari li Syarh Shahih al-Bukhari. Semarang: Maktabah 'Alawiyah.

Ramayulis. (2011). Imu Pendidikan Islam (Edisi Revisi). Jakarta: Kalam Mulia.

Samad, M. Y. (2013). Pendidikan Islam dalam Perspektif Aliran Kalam: Qadariyah, Jabariyah, dan Asy'ariyah. Lentera Pendidikan: Jurnal Ilmu Tarbiyah dan Keguruan, 16(1), 73-82. doi: 10.24252/1p.2013v16n1a6

Siswanto. (2006). Teologi Pendidikan Islam (Diskursus Unity of Knowledge Perspektif Ismail Raj'i Al-Faruqi). Tadris: Jurnal Pendidikan Islam, 1(1), 15-29. doi: 10.19105/jpi.v1i1.195

Suhaimi. (2019). Integrasi Aliran Pemikiran Keislaman: Pemikiran Qadariyah dan Jabariyah yang Bersandar Dibalik Legitimasi Al-Qur'an. El-Furqania: Jurnal Ushuluddin Dan Ilmu-Ilmu Keislaman, 4(2), 108-120. Diambil dari http://ejournal.kopertais4.or.id/madura/index.php/elfurqania/article/view /3296

Sulasmono, P., Ekosiswoyo, R., \& Widodo, J. (2017). The Integration of Local Cultural Wisdom Values in Building The Character Education of Students. International Journal of Education and Research, 5(6), 151-162. Diambil dari https: / /www.ijern.com/journal/2017/June-2017/13.pdf

Sulhan, M. (2018). Pendidikan Karakter Berbasis Budaya dalam Menghadapi Tantangan Globalisasi. Jurnal Visipena, 9(1), 159-172. Diambil dari https: / /visipena.stkipgetsempena.ac.id $/$ ?journal=home\&page=article\&op=vie w\&path $\% 5 \mathrm{~B} \% 5 \mathrm{D}=200$ ?journal=home\&page=article\&op=view $\&$ path $\% 5 \mathrm{~B} \% 5 \mathrm{D}=$ 200

Suryadi, R. A. (2014). Mengusung Pendidikan Islam Perspektif Teologis. Ta'lim: Jurnal Pendidikan Agama Islam, 12(2), 113-125. Diambil dari http://jurnal.upi.edu/file/02_Mengusung_Pendidikan_Islam_Perspektif_Teol ogis_-_Rudi.pdf

Syafi'e, I. (2013). Teologi Pendidikan: Epistemologis, Ontologis, dan Aksiologis. Ijtimaiyya, 6(2), 1-16. Diambil dari 
https: / / media.neliti.com/media/publications /62342-ID-teologi-pendidikanepistemologis-ontolog.pdf

Syihab, M. Q. (2007). Tafsir Al-Mishbah: Pesan, Kesan dan Keserasian Al- Qur'an. Jakarta: Lentera Hati.

Wahyudin, D. (2017). Pendidikan Aswaja sebagai Upaya Menangkal Radikalisme. Jurnal Dinamika Penelitian: Media Komunikasi Sosial Keagamaan, 17(2), 291314. doi: http://dx.doi.org/10.21274/dinamika.2017.17.2.291-314 